\title{
Attitudes towards natural sciences in students from mexico, colombia and peru
}

\section{Actitudes hacia las ciencias naturales en estudiantes de méxico, colombia y perú}

DOI: $10.46932 /$ sfjdv2n5-060

Received in: Oct 1st, 2021

Accepted in: Dec 30th, 2021

\author{
Williams Orlando Tapia Chavez \\ Graduate School of the International University of Andalusia. \\ Calle Américo Vespucio, 2, 41092 Seville, Spain. \\ University Professor of the Department of Education Sciences of the National University of Trujillo. \\ Av. \\ Juan Pablo II s / n - University City, Trujillo, Peru \\ E-mail: billtavez@gmail.com / wtapia@unitru.edu.pe
}

\begin{abstract}
In science didactics the study of attitudes informs about the professional and socio-scientific profiles, for this reason this study has focused its analysis on Mexican, Colombian and Peruvian students to determine their attitudes towards the knowledge, teaching and learning of the natural Sciences. For this, a study was approached with a semantic differential scale allowing to conclude that the students have an intermediate level (between neutral and positive), finding only significant differences depending on the locality.
\end{abstract}

Keywords: Attitudes towards science, Natural Sciences (CCNN), School Science.

\section{RESUMEN}

En didáctica de las ciencias el estudio de las actitudes informa sobre los perfiles profesiones y sociocientíficos, por ello este estudio ha centrado su análisis en estudiantes mexicanos, colombianos y peruanos para determinar sus actitudes hacia el conocimiento, la enseñanza y el aprendizaje de las ciencias naturales. Para ello se abordó un estudio con una escala de diferencial semántico permitiendo concluir que los estudiantes poseen un nivel intermedio (entre lo neutral y lo positivo), hallando sólo diferencias significativas en función a la localidad.

Palabras Clave: Actitudes hacia la ciencia, Ciencias Naturales (CCNN), Ciencia Escolar.

\section{INTRODUCTION}

The quality of socio-scientific decisions and scientific-technological productivity in a society are related to science education (Croxford, 2002; OECD, 2013; Albornoz, 2017). For this reason, school science and what it follows as performance in science and attitudes related to science have become the core of current research for eventual reforms (Ministry of Education Science and Technology of Argentina, 2007; Sormunen \& Köksal, 2008; Kaya, 2012; Calderón, 2015; Karademir \& Ulucinar, 2017). Regarding attitudes, the didactics of science has subscribed to it in the research line called emotiveattitudinal (Vázquez \& Manassero, 2007). 
In this sense, studies indicate that attitudes related to science have dimensions (cognitive, affective and behavioral) (García \& Sánchez, 2006; Cervantes et al., 2009; Hernández et al., 2011) and their approach defines the model of study (Ubillos et al., 2004); it can be qualitative or quantitative (Liaghatdar et al., 2011); implicit or explicit (Gaviria et al., 2013); with a variety of scales (Thurstone, Guttman, Likert or Semantic differential, the latter being the most used) (Ubillos et al., 2004).

On the other hand, such attitudes vary depending on the object to which they are directed (science company, school science, social impact and scientists) (Osborne et al., 2003) and the dimension from which they are born (attitudes towards science / affective and scientific / cognitive attitudes) (Osborne et al., 2003; Acevedo, 2007); in addition to the way it is approached (sociology of science / attitudes related to social aspects or epistemology / attitudes related to the nature of scientific and technological knowledge) (Vázquez \& Manassero, 2007). For this reason, Vázquez \& Manassero (1995) usually divide them into those related to the teaching and learning of science and technology, the interactions between Science, Technology and Society (STS) and with scientific and technical knowledge. For this reason, science didactics has decided to approach it from the CTS and the Nature of Science (NOS) approach, since it collects a lot of information (Vázquez et al., 2006; Akerson \& Donnelly, 2008; Akcay \& Akcay, 2015).

Research also informs us that attitudes related to science are influenced by multiple factors (Genç, 2015) being internal (student's own) or external (student independent) (White \& Harrison, 2012), but it is the teacher and gender the most influential (Osborne et al., 2003). Although for this work the classification of Liaghatdar et al. (2011) (sex, socioeconomic level and teacher). In this sense, it is affirmed that attitudes are associated with the teaching and learning practices generated by the teacher (Solbes, 2011; Timur, 2012; Türer \& Kunt, 2015; Ulukök \& Sari, 2016) and disappear as progresses in the school career (Escudero \& Lacasta, 1984; Murpy \& Eggs, 2003; Martínez \& De Pro, 2009; Akarsu \& kariper, 2013; Cuevas et al., 2015). And although the value for the work of scientists, its importance and usefulness remains intact at the end of the school stage, the same does not happen with the scientific vocation since one ends up seeing studies in science, especially those related to mathematics, physics and science. Chemistry as boring and difficult (Arana et al., 1987; Espinosa \& Román; 1991; Rocard et al., 2007; Polino \& Chiappe, 2009; Bravo, 2012; Falabella et al., 2014; Arias, 2015; Spanish Foundation for Science and Technology, 2011, 2016); being more intense in women (Amal et al., 2011; Desy et al. 2011; Bang \& Backer, 2013; Oluwatelure, 2015) and in societies with a better socioeconomic level (Rocard et al., 2007; Vázquez \& Manassero, 2008a) although there are exceptions (Thom, 2006; Omema, 2014; Sakariyau et al., 2016) when the type of education (coeducation vs differentiated) is taken into account (Vázquez \& Manassero, 2008b), location and family composition (Alrehaly, 2011; Lutfullah, 2013; 
Prakash \& Amaladoss, 2014; Kenar et al., 2016; Hacieminoglu, 2016), giving strong reasons to continue researching and thus clarifying this problem (Mael, 1998).

In this sense, an attempt was made to diagnose the level of attitudes related to teaching-learning in $\mathrm{CCNN}$ in students from three countries belonging to the political-economic group called "Pacific Alliance" (Peru, Mexico and Colombia) ${ }^{2}$ under three categories: attitudes towards the knowledge, teaching and learning of the CCNN. Considering within it the variables of sex and locality. In this way it will be possible to determine and deduce the attitudes related to the school elements (products, resources, contents, objectives, subjects, teachers, etc.) of the CCNN. This can be taken as a small thermometer of the current situation of science education in these countries, without falling into vain generalizations; but encouraging to deepen the study in what attracts attention (especially related to science, research and innovation)

\section{METHODOLOGY}

The present investigation is non-experimental (diagnostic); using the SPSS program. The factor extraction method used has been that of principal components and the rotation method is the Varimax normalization with kaiser, providing a factor analysis reliability index. The Kolmogorov-Smirnov test was used to study the normal distribution. And the non-parametric Kruskall-Wallis test was used to search for significant differences between independent samples, according to sex and locality.

The sample has been selected incidentally reaching 100 students (40 men and 60 women / 40 Peruvians, 28 Colombians and 32 Mexicans). The Peruvians and Mexicans are from the city of Trujillo and Monterrey respectively; while Colombians belong to the rural area of Helicona. The ages of the participants have ranged between 15 and 18 years and belong to the last year of basic education. Furthermore, the sample sizes necessary for each factor load value to be considered significant are based on

achieving a power level of $80 \%$, a significance of 0.05 and the standard errors supposedly twice as large as the conventional correlation coefficients. . For this sample the minimum value necessary for a sample of 100 is 0.55 (Hair et al., 1999).

En este estudio no se ha considerado la edad, el tipo de gestión de la escuela, el nivel socioeconómico y sociocultural de los estudiantes encuestados.

In this study, the age, the type of school management, the socioeconomic and sociocultural level of the surveyed students were not considered.

The semantic differential scale survey was used, which was made up of three categories with the purpose of evaluating "the attitudes towards knowledge, teaching and learning of the CCNN". These 
categories had 12, 11 and 12 variables; and each variable corresponded to three columns (favorable adjectives, punctuations and opposite adjectives). These scores were to evaluate each variable. If an unfavorable (negative attitude) or favorable (positive attitude) adjective was assigned, this was translated as 1 and 3 points respectively. The 2 points were for a neutral position. To obtain the result of each category, the scores of the variables it contained were averaged. This average was classified into five intervals (levels): negative (1), between negative and neutral (greater than 1 and less than 2), neutral (2), between neutral and positive (greater than 2 and less than 3) and positive (3).

The instrument has been validated by Mazzitelli \& Aparicio (2009) whose Crombach alpha for attitudes towards knowledge, teaching and learning have been $0.68 ; 0.82$ and 0.75 respectively.

Complexity hypotheses were developed (Vázquez Bernal et al., 2007; 2012) based on the original questionnaire $^{1}$

\section{DISCUSSION}

For reasons of space, a synthesis of the results is presented.

It was verified (see figure 1 and figure 2) that the attitude towards knowledge (2.33), teaching (2.23) and learning (2.28) of the CCNN ranged between neutral and positive (2.25 points- 74.01\%); Although the best profile is for knowledge but that advantage does not make a significant difference. If the locality and sex are taken into account, certain heterogeneity between the groups is verified, however, significant differences are only manifested

according to the locality. Even when this happens, men (2.31) have a slight advantage over women in terms of attitude level (2.23); but it is the female gender (74.17\%) whose percentage concentration is greater than that of the male $(73.86 \%)$ in the range "between neutral and positive". The only significant difference according to sex was when the attitude was analyzed according to the variable "contribution to personal development" in the teaching category. There, men show a significant advantage $(\mathrm{P}=0.047$ $<0.05$ and with the $95 \%$ confidence level)

\footnotetext{
${ }^{1}$ To know the systematization of the categories with the variables and their respective indicators, the study by Tapia (2017) and Mazzitelli \& Aparicio (2009) can be accessed.
} 
Figure 1. Attitude towards the knowledge, teaching and learning of the natural sciences, according to sex and locality

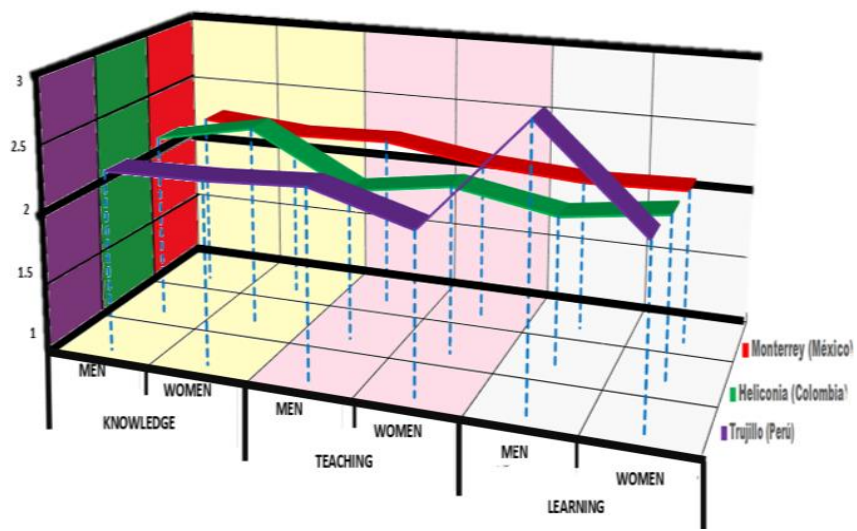

On the other hand, it was found that in localities with more unfavorable socioeconomic conditions the attitude is better. This is the case of the Trujillanos (2.38 points- $78.13 \%)$, of the Colombian rural environment and of the South American countries (Peru and Colombia).

Let us remember that of the three countries the best and the worst economic systems are in Mexico and Peru respectively; and generally the economies of the north tend to have more advantages than those of the south.

These findings are supported by studies that argue that attitudes towards science and attitudinal differences by sex are better and shorter, respectively, in societies with a low socioeconomic level (ROSE in Vázquez \& Manassero, 2009; Sakariyau, et al., 2016).

The explanation for this phenomenon can be given if the Scandinavian paradox is taken into account; which indicates that when there are no socioeconomic advantages, freedom of choice diminishes, therefore vocational aspirations are dismissed or postponed and options of all kinds are taken to get out of poverty; like it or not. This is reinforced by the type of teaching they receive in their schools. It is known that in countries and societies with low socioeconomic levels, too much student-centered teaching methods (of a constructivist nature) are practiced, which although they do not achieve good performance in science, they do manage to obtain better attitudes towards science, both in terms of men as well as women (OECD, 2016). 
Figure 2. Percentage of students on their attitude level towards knowledge, teaching and learning of natural sciences, according to sex and locality.

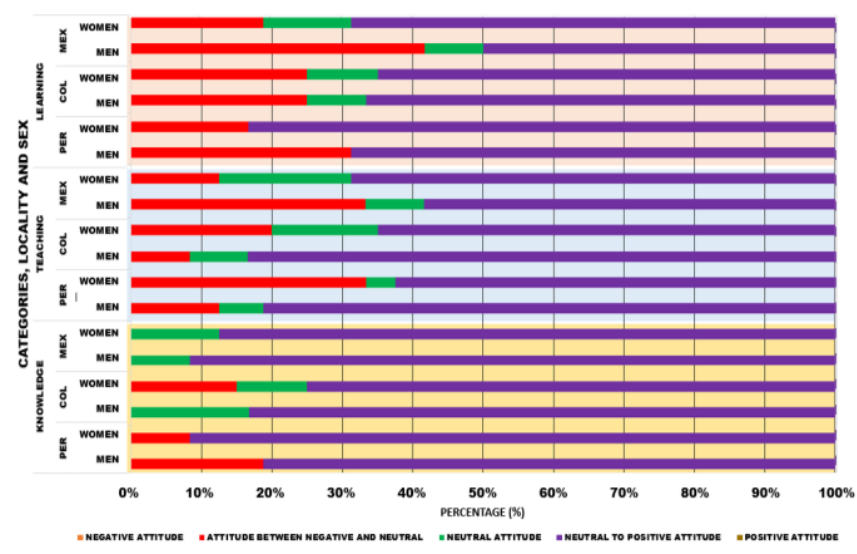

The explanation for this phenomenon can be given if the Scandinavian paradox is taken into account; which indicates that when there are no socioeconomic advantages, freedom of choice diminishes, therefore vocational aspirations are dismissed or postponed and options of all kinds are taken to get out of poverty; like it or not. This is reinforced by the type of teaching they receive in their schools. It is known that in countries and societies with low socioeconomic levels, too much student-centered teaching methods (of a constructivist nature) are practiced, which although they do not achieve good performance in science, they do manage to obtain better attitudes towards science, both in terms of men as well as women (OECD, 2016).

On the other hand, analyzing the variables of each category (see figure 3 ) we discovered that the variables of the knowledge category obtained the best and worst scores in "importance (2.80)" and "ease (1.41)" respectively; which ratifies the findings of the Spanish Foundation for Science and Technology (2011, 2016), Polino \& Chiappe (2009), Arias, 2015, among others; on the ambivalence that one has for scientific knowledge (it is important, but it is difficult) The same is verified with the variables of the learning category. Regarding the teaching category, the score of its variables is located slightly above the intermediate level; Therefore, it can be deduced that for the respondents there are doubts as to the contribution that CCNN teaching has in their training for work and their ethical (values), cognitive, personal and cultural development. This same doubt is manifested when the same variables are analyzed but within the categories of knowledge and learning. Nor are they sure if the teaching they receive has a variety of resources and strategies; however they affirm with certainty that they are "interested" in being taught CCNN and that such teaching is "something easy". 
Figure 3. Attitude towards knowledge, teaching, and learning of natural sciences, according to variable

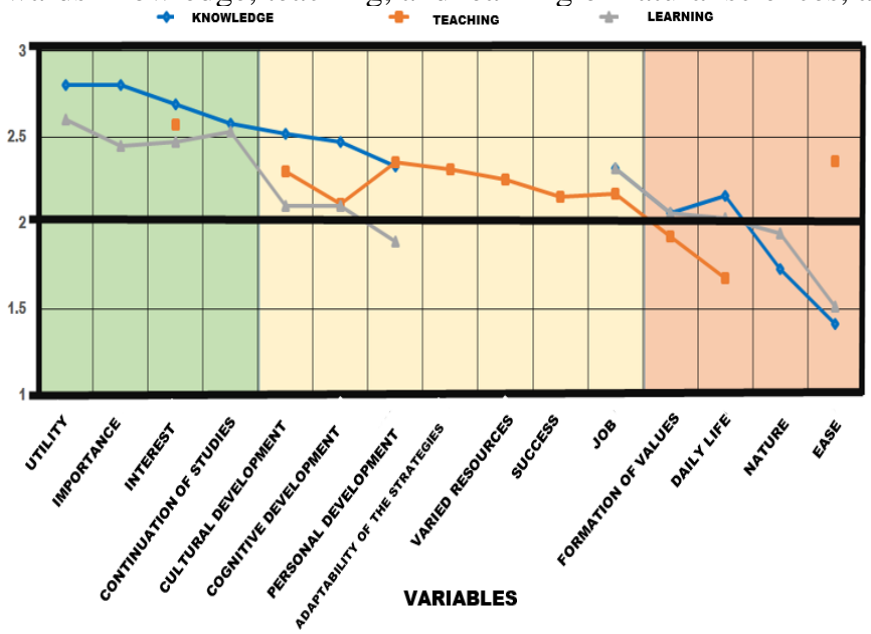

This can be explained by the OECD report (2016) who indicates that in developing countries such as Latin America, teacher training is weak, so they tend to use student-centered (constructivist) methods, so that teachers Students feel motivated to learn, but they do not achieve good results since the teacher is strongly established in the method by problems or discovery, leaving aside the content. This is the reason why the student claims to feel easy and interesting the teaching of CCNN that she receives, since who does not like to play the scientist? But when he is asked about the contribution of that knowledge to his life, it is verified that he does not find it, and it is because he does not have the knowledge systematized, since he did not receive it from his teacher. The same holds for Enkvist (2012), Tobias \& Duffy (2009) among many others, since science training is more fruitful with teacher-led teaching (traditional), since with constructivism so far there are no favorable results, Except when it comes to improving the attitude towards science somewhat; although it is a misleading profile; because it is based on a wrong concept of scientific work.

On the other hand, as mentioned, significant differences have only been found when they are analyzed according to the student's place of origin.

In this sense, it was verified that in the knowledge category there are significant differences on the variables "need to continue studying" ( $\mathrm{P}=0.004<0.05$ and with the $95 \%$ confidence level) and "contribution to cognitive development" ( $\mathrm{P}=0.000<0.05$ and with a confidence level of $95 \%)$ between the towns of Trujillo (Peru), Heliconia (Colombia) and Monterrey (Mexico). Therefore, it is understood that Colombians and Mexicans show significantly higher and lower average levels of attitude towards both variables, respectively. In the teaching category, the first was in the variable "the use of varied resources" ( $\mathrm{P}=0.000<0.05$ and with the $95 \%$ confidence level), the second in "teaching success" $(\mathrm{P}=$ $0.009<0.05$ and with the $95 \%$ confidence level). In both, the best profile is of the Peruvians. The third variable has been "favors cultural development" $(\mathrm{P}=0.004<0.05$ and with the $95 \%$ confidence level) favoring Mexicans. 
Figure 4. Significant differences between independent groups according to location, variable and category $\rightarrow$ MEXICO - PERU \pm COLOMBIA

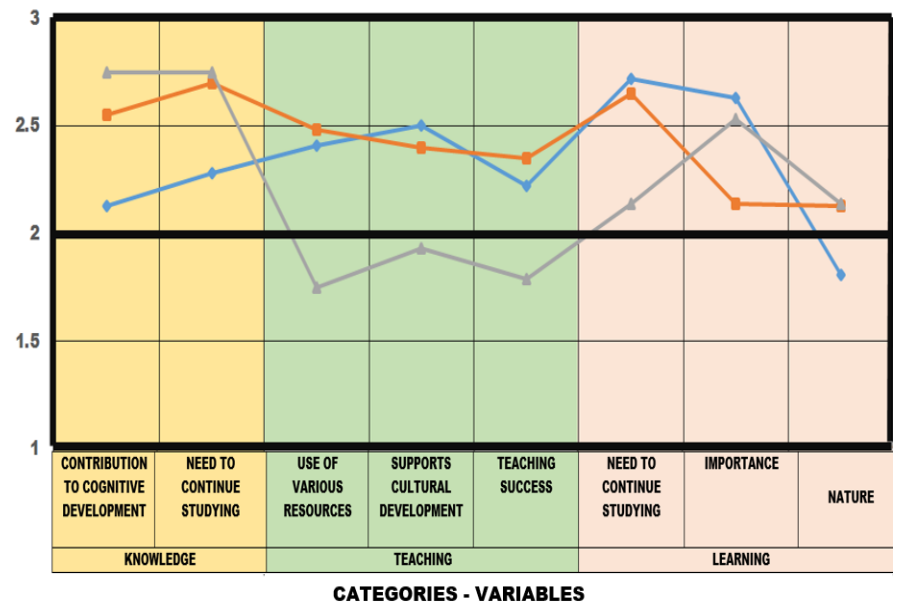

For the learning category, the significant differences were accentuated in the variables of "nature" $(\mathrm{P}=0.038<0.05$ and with the $95 \%$ confidence level), "importance" $(\mathrm{P}=0.016<0.05$ and with the confidence level of the 95\%) and "need to continue studying" ( $\mathrm{P}=0.001<0.05$ and with the $95 \%$ confidence level). Of the three, the latter is the one with the greatest significant difference found. In addition, in the last two variables, Mexicans take advantage, but in the first, Peruvians and Colombians stand out at the same time.

Taking into account the minimum accepted values of composite reliability $(\mathrm{FC}=0.7)$ and of the extracted mean variance $(\mathrm{AVE}=0.5)$, we can say that the values of the composite reliability $(\mathrm{FC}=0.74)$ and that of the extracted mean variance $(\mathrm{AVE}=0.50)$, starting from the factorial weights and the measurement errors extracted from the confirmatory FA, indicate adequate values for the reliability and relevance of the factorial analysis.

In this sense, the factors found for the category knowledge, teaching and learning have been 4, 3 and 4 respectively. However, we will highlight only some of them. In the knowledge category, the factor made up of the variable "importance", "need at work" and "usefulness" stood out. In the teaching category, two factors stood out whose associated variables were "ease" and "adaptability of strategies", as well as "contribution to personal development", "teaching success" and "contribution to the formation of values". Finally, in the learning category, a factor was highlighted, which was made up of "need to continue studying", "usefulness" and "importance".

From these factors it can be deduced that the interest and usefulness for knowledge of the natural sciences depend on its association with work. That is why it is important to learn it, since it not only gives job opportunities, but also allows you to continue studying.

Its ease depends on the degree of adaptability of the strategies. Likewise, the success of the teaching of natural sciences is associated with the personal and ethical contribution of the student. 


\section{CONCLUSIONS}

The attitude towards the knowledge, teaching and learning of the CCNN oscillates between the neutral and the positive, being able to say that it is intermediate. This attitude is the same in men and women (there are no significant differences), however there are significant differences when the locality is taken into account. In this case, it is found that the most socioeconomically disadvantaged (such as Peruvians) have a better attitudinal profile.

On the other hand, it is verified, as in the diverse existing bibliography, that students consider important, useful and necessary for work and studies both knowledge and learning of natural sciences; however it is boring and difficult. This could be understood if one takes into account the statements about teaching and its characteristics, which do not stand out either. 


\section{REFERENCES}

Acevedo Díaz, J. A. (2007). Attitudes related to science and technology in the PISA 2006 study. Eureka Journal on Science Teaching and Dissemination, 4 (3), 394-416. E-ISSN: 1697-011X.

Akarsu, B. \& kariper, A. (2013). Upper secondary school pupils 'attitudes towards natural science. European Journal of Physics Education, 4. (1), 78-87. EISSN-1309-7202

Akcay, B. \& Akcay, H. (2015). Effectiveness of science-technology-society (sts) instruction on student understanding of the nature of science and attitudes toward science. International Journal of Education in Mathematics, Science and Technology, 3. (1), 37-45.

Akerson, V. L. \& Donnelly, L. A. (2008). Relationships among learner characteristics and preservice elementary teachers' views of nature of science. Journal of Elementary Science Education, 20. (1, 45-58. ISSN-1090-185X.

Albornoz, M. (2017). The State of Science: Main Ibero-American / Inter-American Science and Technology Indicators, 2017. Buenos Aires: REDES-RICYT.

Alrehaly, E. D. (2011). Parental attitudes and the effects of ethnicity: how they influence children's attitudes toward science education. The University of Arkansas

Amal I., Khalil, M. O., Abou, H., Eman, S. \& Dawood. (2011). Coeducation versus single sex education: impact on self esteem and academic achievements among nursing 'students. American Science, 7. (12), 176-184.

Arana Pérez, J., Escudero Escorza, T., Garces Campos, R. \& Palacian Gil, E. (1987). Image of science subjects in the transition from basic to secondary education. Electronic Journal of Science Teaching, 5 (1), 10-15

Argentina, Ministry of Education, Science and Technology. (2007). Improving Science and Mathematics Teaching: A National Priority. Buenos Aires: Author.

Arias Schreiber, M. (2015). Study on the different factors that influence young people to lean towards a scientifictechnical training. Lima: National Council of Science, Technology and Technological Innovation-CONCYTEC

Bang, E. \& Baker, D. R. (2013). Gender differences in Korean high school students' science achievements and attitudes towards science in three different school settings. Mevlana International Journal of Education, 3. (2), $27-$ 42.

Bravo Murillo, (2012). Science, technology and innovation for development and social cohesion: Ibero-American program in the bicentennial decade. Madrid: Organization of Ibero-American States for Education, Science and Culture - OEI

Calderón García, R. (2015). The perception of science, technology and innovation in middle and high school students in the Metropolitan Area of Guadalajara, Mexico. RIDE, Ibero-American Journal for Educational Research and Development, 6 (11). E-ISSN: 2007-7467.

Cervantes Castro, R. D., Cappello García, H. M. \& Castro Tovar, R. D. (2009). Analysis of teaching attitudes towards science education. A study of the science teaching program applied to elementary schools in Ciudad Victoria, Tamaulipas. International Journal of Social Sciences and Humanities, SOCIOTAM, 1 (19), 9-26.

Croxford, L. (2002). Participation in science, engineering and technology at school and in higher education. Report to Scottish Executive Enterprise and Lifelong Learning Department. Center for Educational Sociology University of Edinburgh. Scotland. 
Cuevas Romo, A., Vega, M. \& Hernández Sampieri, R. (2015). Mexican students at primary school and their perception and attitude towards science. European Journal of Science and Mathematics Education, 3. (4), 390-395. ISSN-2301-251X

Desy, E. A., Peterson, S. A. \& Brockman, V. (2011). Gender differences in science-related attitudes and interests among middle school and high school students. Science Educator, 20. (2), 23-30. ISSN-1094-3277.

Enkvist, I. (2012). Good and Bad Education: International Examples. Encounter Editions. Spain.

Escudero Escorza, T. \& Lacasta Zabalza, E. (1984). The scientific attitudes of future teachers in relation to their knowledge. Electronic Journal of Science Teaching, 175-180.

Espinosa, J. \& Román, T. (1991). Attitudes toward science and pending assignments: two factors affecting science performance. Electronic Journal of Science Teaching, 9. (2), 151-154.

Falabella, I., Cocconi, M. \& Rocha, A. (2014). The learning experience in the natural sciences and vocational choice. A study in pre-university students. Ibero-American Journal of Education, 65 (2), 1-15.

García Ruiz, M. \& Sánchez Hernández, B. (2006). Attitudes related to natural sciences and their repercussions on the teaching practice of primary school teachers. Educational Profiles, 27. (1), 61-89. ISSN: 0185-2698.

Gaviria Stewart, E., Cuadrado Guirado, M. I. \& Fernández Arregui, S. (2013). Introduction to social psychology. Spain: Editorial Sanz y Torres.

Genç, M. (2015). The effect of scientific studies on students' scientific literacy and attitude. Ondokuz Mayis University Journal of Faculty of Education, 34. (1), 141-152. doi: 10.7822 / omuefd.34.1.8.

Hacieminoglu, E. (2016). Elementary school students' attitude toward science and related variables. International Journal of Environmental and Science Education, 11. (2), 35-52. EISSN-1306 3065.

Hair, J.; Anderson, R .; Tatham, R. \& Black, W. (1999). Multivariate analysis. 5th Edition. Madrid: Prentice Hall.

Hernández, V., Gómez E., Maltes, L., Quintana, M., Muñoz, F., et al. (2011). The attitude towards the teaching and learning of science in students of Basic and Secondary Education of the Province of Llanquihue, Los Lagos RegionChile. Pedagogical Studies XXXVII, 1, 71-83

Karademir, E. \& Ulucinar, U. (2017). Examining the relationship between middle school students' critical reading skills, science literacy skills and attitudes: a structural equation modeling. Journal of Education in Science, Environment and Health, 3. (1), 29-39. EISSN-2149-214X.

Kaya, H. (2012). An investigation into upper elementary students' attitudes towards science. European Journal of Physics Education, 3. (2), 22-33. EISSN-1309-7202.

Kenar, I., Mücahit, K. \& Halil I. D. (2016). Determination of motivation of 5th grade students living in rural and urban environments towards science learning and their attitudes towards science-technology course. Journal of Education and Training Studies, 4. (7), 155-167. ISSN-2324-805X.

Liaghatdar, M. J., Soltani, A. \& Abedi, A. (2011). A validity study of attitudes toward science scale among Iranian secondary school students. International Education Studies, 4. (4), 36-46. ISSN-1913-9020.

Lutfullah, T. (2013). In-service Turkish elementary and science teachers' attitudes toward science and science teaching: a sample from usak province. Science Education International, 24. (4), 437-459. ISSN-2077-2327.

Mael, F. A. (1998). Single-sex and coeducational schooling: relationships to socioemotional and academic development. Review of Educational Research, 68. (2), 101-129. ISSN-0034-6543. 
Martínez Artero, R. N. \& De Pro Bueno, A. (2009). Attitudes towards science of primary school students in the Murcia region. Department of Didactics of Experimental Sciences. University of Murcia. Spain.

Murpy, C. \& Beggs, J. (2003). Children's perceptions of school science. School Science Review, 84 (308), 109116.

Mazzitelli, C. A \& Aparicio, M. T. (2009). The Attitudes of Students towards Natural Sciences, in the Framework of Social Representations, and their Influence on Learning. Electronic Journal of Science Teaching, 1 (8), 193-215

OECD (2013). Latin American Economic Outlook 2014. Logistics and Competitiveness for Development. Economic Commission for Latin America and the Caribbean (ECLAC) and Organization for Economic Cooperation and Development (OECD)

Omema Mostafa, K. G. (2014). The effect of differentiating instruction using multiple intelligences on achievement in and attitudes towards science in middle school students with learning disabilities. International Journal of PsychoEducational Sciences, 3. (3), 109-117

Osborne, J., Simon, S. \& Collins, S. (2003). Attitudes towards science: a review of the literature and its implications. International Journal of Science Education, 25. (9), 1049-1079.

Polino, C \& Chiappe, D. (2009). Perception of young people about science and the scientific profession (Project of the Center for Higher University Studies of the Organization of Ibero-American States).

Observatory of Science, Technology and innovation. Oluwatelure, T. A. (2015). Gender Difference in Achievement and Attitude of Public Secondary School Students towards Science. Journal of Education and Practice, 6. (2), 8792. ISSN-2222-1735Rocard, M., Csermely, P., Jorde, D., Lenzen, D., Walberg Henriksson, H. \& Hemmo, V. (2007). Science Education now: a renewed pedagogy for the future of europe. European Commission. Directorate Community Research. Brussels. ISSN 1018-5593

Prakash, S. \& Amaladoss, X. S. (2014). A study on attitude of urban and rural college student teachers towards science. Journal on Educational Psychology, 7. (3), 13-17. ISSN-0973-882.

Sakariyau, A. O., Taiwo, M. O. \& Ajagbe, O. W. (2016). An Investigation on Secondary School Students 'Attitude Towards Science in Ogun State, Nigeria. Journal of Education and Practice, 7 (28), 125-128. ISSN ISSN 2222$288 \mathrm{X}$.

Solbes, J. (2011). Why does the science student body decrease? Still. Didactics of Experimental Sciences, (67), 5361

Sormunen, K. \& Köksal, M. (2008). Advanced science students 'understandings on nature of science in Finland. European Journal of Educational Research, 3. (4), 167-176. EISSN-2165-8714.

Spain. Spanish Foundation for Science and Technology-FECYT. (2011). Social perception of science and technology 2010. Madrid. Author.

Spain. Spanish Foundation for Science and Technology-FECYT. (2016). VIII survey of social perception of science, informative dossier. Madrid. Author

Tapia Chavez, Williams. (2017). Attitudes towards natural sciences in students from Monterrey (Mexico), Heliconia (Colombia) and Trujillo (Peru). Final Master's Project. International University of Andalusia. Spain. http://hdl.handle.net/10334/3878

Timur, B. (2012). Determination of factors affecting preschool teacher candidates' attitudes towards science teaching. Educational Sciences: Theory and Practice, 12. (4), 2997-3009. ISSN-1303-0485 
Tobias, Sigmund \& Duffy, Thomas M. (2009). Constructivist intrsuction success or failure? Routledge Taylor \& Francis Group. Londres.

Türer, B. \& Kunt, H. (2015). A review of relationship between prospective science teachers' attitudes towards science education and their self-efficacy. Journal of Education and Training Studies, 3. (6), 166-178. ISSN-2324$805 \mathrm{X}$.

.Ubillos, S., Mayordomo, S. \& Páez, D. (2004). Attitudes: Definition and Measurement. Components of Attitude. Reasoned Action and Planned Action Model. In D. Páez, I. Fernández, S. Ubillos, \& E. Zubieta (Coords.), Social psychology, culture and education (pp. 301-326). Madrid: Pearson Prentice Hall.

Ulukök, S. \& Sari, U. (2016). The effect of simulation-assisted laboratory applications on pre-service teachers' attitudes towards science teaching. Universal Journal of Educational Research, 4. (3), 465-474. ISSN-2332-3205.

Vázquez Alonso, A \& Manassero Mas, M. A. (1995). Attitudes related to science: a conceptual review. Electronic Journal of Science Teaching, 13. (3), 337-346.

Vázquez Alonso, A., Manassero Mas, M. A. \& Acevedo Díaz, J. A. (2006). An analysis of complex multiple-choice science - technology - society items: methodological development and preliminary results. DOI 10.1002 / sce. 20134.

Vázquez Alonso, A. \& Manassero Mas, M. A. (2007). In defense of attitudes and emotions in science education (I): evidence and general arguments. Eureka Magazine on Science Teaching and Dissemination, 2 (4), 247-271. EISSN: 1697-011X

Vázquez-Bernal, B., Jiménez Pérez, R. \& Mellado, V. (2007). The professional development of science teachers as integration, reflection and practice. The Complexity Hypothesis. Eureka Magazine on Science Teaching and Dissemination, 4 (3), 372-393. E-ISSN: 1697-011X.

Vázquez Alonso, A. \& Manassero Mas, M. A. (2008a). The decline in student attitudes towards science: a disturbing indicator for science education. Eureka Magazine on Science Teaching and Dissemination, 5 (3), 274-292. ISSN: 1697-011X.

Vázquez Alonzo, A. \& Manassero Mas, M. A. (2008b). The scientific and technological vocation of girls in secondary school and differentiated education. Bordon, 60 (3), 149-163.

Vázquez Alonso, A. \& Manassero, M. A. (2009). The relevance of science education: attitudes and values of students related to science and technology. Electronic Journal of Science Teaching, 27 (1), 33-48

Vázquez-Bernal, B., Mellado, V., Jiménez Pérez, R. \& Taboada, M. C. (2012). The process of change in a science teacher's professional development: A case study based on the types of problems in the classroom. Science Education, 96 (2), 337-363. ISSN: 1098-237X.

White, E. L. \& Harrison, T. G. (2012). Uk school students' attitudes towards science and potential science-based careers, Acta Didactica Napocensia, 5. (4), 1-10. EISSN-2065-1430. 